\title{
Body size, age structure and survival rates in two populations of the Beyșehir frog Pelophylax caralitanus
}

\author{
Ayşen Günay Arısoy ${ }^{1}$ Eyup Başkale ${ }^{1}$ \\ 1 Department of Biology, Faculty of Arts and Science, Pamukkale University, Denizli, Turkey \\ http://zoobank.org/CB8114C2-E46E-4D17-A1BE-C8E1D43457CD \\ Corresponding author: Eyup Başkale (ebaskale@pau.edu.tr; eyupbaskale@gmail.com)
}

Academic editor: Günter Gollmann • Received 29 April 2019 • Accepted 29 August 2019 • Published 10 September 2019

\begin{abstract}
In many amphibians, skeletochronology is a reliable tool for assessing individual mean longevity, growth rates and age at sexual maturity. We used this approach to determine the age structure of 162 individuals from two Pelophylax caralitanus populations. All individuals exhibited Lines of Arrested Growth (LAGs) in the bone cross-sections and the average age varied between 4.5 and 5.4 years in both Işıklı and Burdur populations. Although intraspecific age structure and sex-specific age structure did not differ significantly between populations, we found that the Işıklı population had a lower body size in the same age class, had lower growths rates and lower values of survival rates and adult life expectancy than the Burdur population.
\end{abstract}

\section{Key Words}

Amphibia, longevity, age at sexual maturity, growth rates, survival rate

\section{Introduction}

Growth rate and body size are important intraspecific characteristics for adult amphibians. Skeletochronology is a reliable tool for assessing individual mean longevity, growth rates and age at sexual maturity (Castanet et al. 1993; Smirina 1994). Lines of Arrested Growth (LAGs) are annually developed in the long bones during periods of unfavourable growing conditions, such as winter and they allow accurate calculations for determining the age of anurans. This technique was successfully performed on the phalanges of many amphibian species, hence it represents a powerful technique (Olgun et al. 2005; Guarino and Erişmiş 2008; Üzüm and Olgun 2009; Üzüm et al. 2011; Altunışık and Özdemir 2013; Sinsch 2015). This technique is also used for other endangered species and allows individuals to be marked for field study and skeletal elements to be obtained for skeletochronology without sacrificing the individuals (Castanet and Smirina 1990; Guarino et al. 1999). In addition, this technique, which uses seasonally variable physiological activity, has proven to be an excellent tool in evaluating population age models in amphibian species (Esteban and Sanchiz 2000).

Pelophylax caralitanus, Beyşehir frog (Arıkan, 1988) was originally described as a nominant subspecies of Pelophylax ridibundus by Bodenheimer (1944). Arıkan (1988) described the Beyşehir population from Lake Beyşehir as a new subspecies ( $R$. r. caralitana), based on morphometric characters. However, Beerli et al. (1994) claimed that $R$. r. caralitana is not a new subspecies and that $R$. r. caralitana and Rana levantina should be regarded as synonyms of Rana [Pelophylax] bedriagae. The subsequent karyological, morphological, genetic and bio-acoustical studies on the taxonomy of the Beyşehir population showed that $R$. r. caralitana is different from both Pelophylax ridibundus and Pelophylax bedriagae (Arıkan et al. 1994; Alpagut and Falakalı 1995; Budak et al. 2000; Kaya et al. 2002). As a result of taxonom- 
ic assessments, $P$. caralitanus is an endemic species of Turkey and is distributed only within the Anatolian Lake District and Konya plain of Turkey (Jdeidi 2000; Plötner et al. 2001). Previous studies have shown that P. caralitanus lives in permanent wetlands with rich aquatic vegetation, including ponds, rain ponds, streams, rivers and irrigation canals (Arikan 1988; Atatür et al. 1989-1990, Jdeidi 2000; Plötner et al. 2001; Kaya et al. 2002; Düşen et al. 2004; Başkale and Çapar 2016; Başkale et al. 2017). Pelophylax caralitanus has been listed as Near Threatened (NT) because of ongoing threats from habitat loss and over-exploitation (Öz et al. 2009).

The primary aim of our study was to determine the sex-specific variability of age and size at maturity and longevity of $P$. caralitanus. We also discuss the age distribution of a cognate species in different geographic ranges.

\section{Materials and methods}

\section{Study sites}

Our study was performed on Burdur Lake and Işıklı Lake. Both lakes, which have been fed by an underground water source, rain and other permanent water sources for many years, are natural habitats for amphibians.

The Burdur Lake population $\left(37^{\circ} 38^{\prime} \mathrm{N}, 30^{\circ} 03^{\prime} \mathrm{E} ; 859\right.$ $\mathrm{m}$ a.s.1.) is located adjacent to villages of Burdur province. Burdur Lake covers $250 \mathrm{~km}^{2}$ and attains a maximum depth of $110 \mathrm{~m}$. This area is surrounded by agricultural land and consists of a small wetland and a channel that is connected to Burdur Lake. The periphery and water body of this site is densely covered by aquatic vegetation. Agricultural activities, such as supplying water for irrigation and amateur fishing (for Carassius gibelio), are performed on this site.

Işıklı Lake population $\left(38^{\circ} 12^{\prime} \mathrm{N}, 2^{\circ} 49^{\prime} \mathrm{E} ; 820 \mathrm{~m}\right.$ a.s.1.) is located in Çivril, Denizli province. Işıklı Lake covers $73 \mathrm{~km}^{2}$ and has a maximum depth of $7 \mathrm{~m}$. This area is surrounded by settlements and agricultural areas and consists of small streams and man-made channels. There is also an energy power plant on the southwest of the lake. The periphery and water body of this site are covered by aquatic vegetation. At irregular intervals, trees such as Salix sp. and broken branches of these trees have floated on the water surface. Agricultural activities, such as supplying water for irrigation, have caused a considerable decrease in the water level of the lake (up to $3 \mathrm{~m}$ ) from July to September. Additionally, camping, picnic activities and amateur fishing (for Esox lucius and Tinca tinca) are undertaken on this site.

\section{Field studies}

Individuals of $P$. caralitanus were captured by two or three persons with a dip net or by hand after sunset using flashlights during the 2015-2018 breeding seasons. The
Snout-Vent Lengths (SVL) were obtained with a dial caliper at a $0.02 \mathrm{~mm}$ accuracy. We determined the sex of the individuals, based on the secondary sexual organs: males have tubercules on the first finger of their front foot and a paired vocal sac on their head.

\section{Laboratory studies}

According to the skeletochronology study literature, to determine the age of the species, the longest digit of the hind foot was removed and fixed in $70 \%$ ethanol. The skeletochronology procedure followed the previous studies (Castanet and Smirina 1990; Castanet et al. 1993; Smirina 1994). The bones of each animal were cleaned from the tissues, washed in running water for 12-14 h, decalcified for 4-6 h in 5\% nitric acid and then placed in distilled water overnight. The bones were dehydrated using graded ethanol and then cleared in xylene, before embedding in paraffin. Using a rotary microtome, we obtained 14-16 $\mu \mathrm{m}$ thick cross-sections from the central region of the diaphysis, stained them with Ehrlich's Haematoxylin and Eosin and analysed them under an Olympus CX31 light microscope that was equipped with a digital camera, Kameram 5. The age of the amphibian was determined by two of the authors who independently counted the number of Lines of Arrested Growth (LAGs) present in each of the bone sections.

\section{Statistical analyses}

The data were normally distributed (Kolmogorov-Smirnov D test, all $\mathrm{P}>0.05$ ), thus allowing comparisons using parametric tests. We used an independent samples t test to compare the sexes morphometrically. We assumed that the age at first reproduction (Age at Maturity: AM) is the lowest age recorded amongst the breeding individuals.

The sexual dimorphism index (SDI) was calculated as SDI $=$ (mean length of the larger sex / mean length of the smaller sex $) \pm 1$. The plus-minus sign $( \pm$ ) gives +1 if males are larger than females, defining the result as negative and -1 if females are larger than males, defining the result as positive. This formula was generated by Lovich and Gibbons (1992).

Growth was estimated according to the Bertalanffy equation (Bertalanffy 1938) which was previously used in several studies on amphibians (Miaud et al. 2001; Gül et al. 2011; Üzüm et al. 2011; Erişmiş 2018). The modified growth formula is;

$$
\mathrm{SVL}_{\mathrm{t}}=\mathrm{SVL}_{\text {max }}-\left(\mathrm{SVL}_{\text {max }}-\mathrm{SVL}_{\text {met }}\right) \mathrm{e}^{-\mathrm{k}(\mathrm{t}-\mathrm{t} \text { met })}
$$

where $\mathrm{SVL}_{\mathrm{t}}$ is the average body length at age $\mathrm{t}$; $\mathrm{SVL}_{\max }$ is the asymptotic maximum body length; $\mathrm{SVL}_{\text {met }}$ is the body length at metamorphosis that was used to calculated newly metamorphosed individuals at the end of the summer 
(25-30 August 2018) (fixed to mean $32.7 \pm 3.415 \mathrm{~mm}$ for the Burdur population and $31.9 \pm 3.625 \mathrm{~mm}$ for the Işıl 1 population); $\mathrm{k}$ is the body growth rate coefficient (units are $\left.\mathrm{yr}^{-1}\right)$ that defines the shape of curve; $\mathrm{t}_{\text {met }}$ is the age at metamorphosis (0.3).

The parameters $\mathrm{SVL}_{\max }$ and $\mathrm{k}$ and their asymptotic confidence intervals (CI) were estimated by non-linear regression. Annual growth rate (AGR) is the rate of the difference between the mean SVL of the individuals in each age group $i$ and the mean SVL in each age group i-1 (AGR = the mean SVL of the Age ${ }_{i}-$ the mean SVL of the $A \mathrm{Ag}_{\mathrm{i}-1} /$ The mean SVL of the $\mathrm{Age}_{\mathrm{i}-1}$ ). This formula was obtained from Erişmiş (2018). All statistical analyses were conducted using SPSS ver. 20.0 (SPSS 2011).

The survival rates assume a constant survival rate across all age classes and sampling of individuals with respect to age, which were estimated from Robson and Chapman's (1961) formula: $\mathrm{S}=\mathrm{T} /(\mathrm{R}+\mathrm{T}-1)$ where $\mathrm{S}$ is the finite annual survival rate estimate, $\mathrm{T}$ is $\mathrm{N}_{1}+2 \mathrm{~N}_{2}+3 \mathrm{~N}_{3}+\ldots$. and $\mathrm{R}$ is $\Sigma \mathrm{N}_{\mathrm{i}}$, where $\mathrm{N}_{\mathrm{i}}$ is the number of individuals in age group $\mathrm{i}$.

Adult life expectancy (ESP) is the expected average age and differs from the longevity value, which is the highest recorded age amongst individuals. Adult life expectancy was derived from Seber's formula (Seber 1973): $\mathrm{ESP}=0.5+1 /(1-\mathrm{S})$ where $\mathrm{S}$ is the survival rate.

\section{Results}

A total of 162 individuals (Burdur Lake $=35 \AA, 35 q$ and 13 subadults; Işıklı Lake $=34 \hat{\circ}, 38 \bigcirc$ and 7 subadults) were examined in this study. All examined bones in adult frogs had well-defined LAGs and endosteal bones with visible layers (Figure 1). They appeared as thin and approximate concentric layers, more intensely stained than the rest of the cross-section.

The mean SVL was $84.12 \pm 1.83 \mathrm{~mm}$ (mean $\pm \mathrm{SE}$; range $=55.2-115.4 \mathrm{~mm}, \mathrm{n}=73)$ in females and 76.67 $\pm 1.48 \mathrm{~mm}$ (range $=52.9-105.1, \mathrm{n}=69)$ in males. The mean SVL $(\mathrm{t}=7.109$, $\mathrm{df}=139, \mathrm{P}<0.01)$ was significantly different between males and females which means that females were significantly larger than males. The body size comparisons according to ages were presented in Table 1. The sexual dimorphism index was calculated as 0.1 , indicating a female bias. Furthermore, the SVL of individuals showed statistically significant differences between Işıklı and Burdur populations $(\mathrm{t}=2.933$, df $=70, \mathrm{P}<0.05$ for females; $\mathrm{t}=2.841, \mathrm{df}=67, \mathrm{P}<0.05$ for males). These results showed that the highest SVL for both sexes were found in the Burdur population. These data were supported by the sex specific asymptotic size of individuals in both populations.

The mean ages of males and females were calculated as $5.2 \pm 0.25$ and $4.6 \pm 0.22$ years, respectively. Age, size and growth parameter variations of both populations are given in Table 2. The age distributions were not significantly different between sexes in both populations
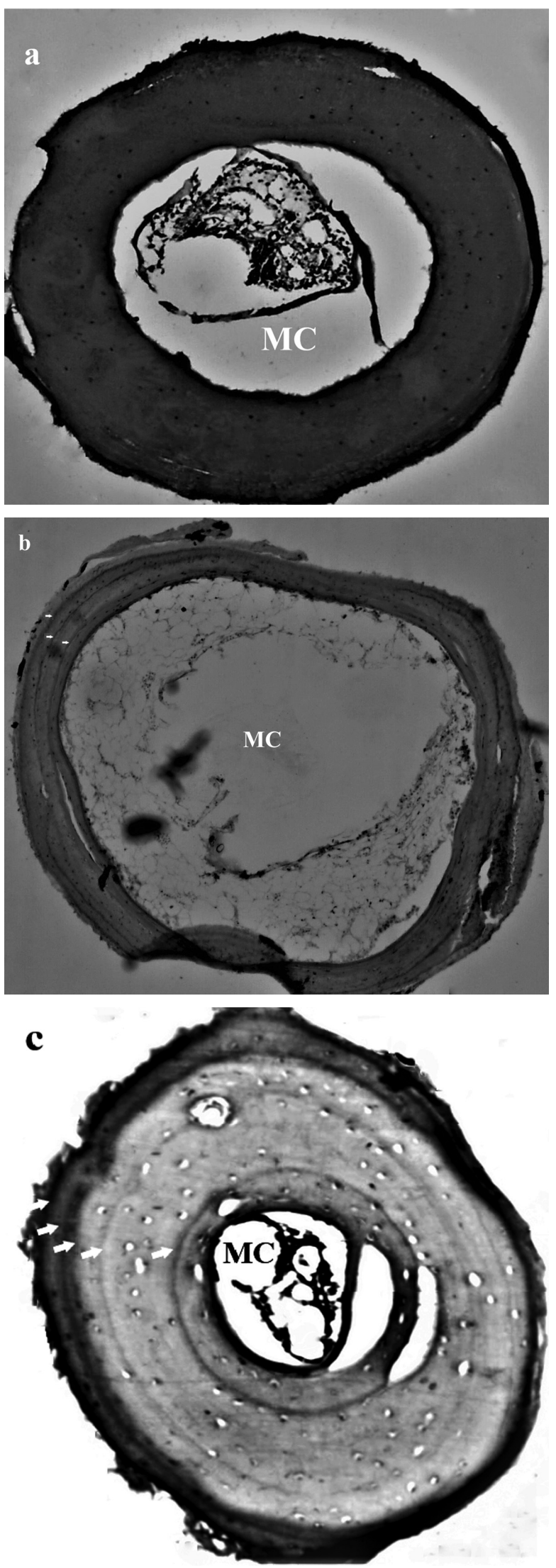

Figure 1. Phalangeal cross-sections (16 $\mu \mathrm{m}$ thick) of $P$. caralitanus. The white arrows show LAGs in the periosteal bone: (a) Newly metamorphosed individuals with $33.6 \mathrm{~mm}$ SVL Male: 3 LAGs with $56.3 \mathrm{~mm}$ SVL, (b) Female, 5 LAGs with $73.3 \mathrm{~mm}$ SVL. MC=Marrow cavity. 
Table 1. Age and sex dependent body size differentiations of $P$. caralitanus in two populations.

\begin{tabular}{|c|c|c|c|c|c|c|c|c|c|c|c|c|c|c|c|c|c|}
\hline & \multirow[t]{2}{*}{ Age } & \multicolumn{4}{|c|}{ Newly Metamorphosed (MT) } & \multicolumn{4}{|c|}{ Subadults (SA) } & \multicolumn{4}{|c|}{ Female (F) } & \multicolumn{4}{|c|}{ Male (M) } \\
\hline & & $\mathbf{n}$ & Min-Max & Mean SVL & S.E & $\mathbf{n}$ & Min-Max & Mean SVL & S.E & $\mathbf{n}$ & Min-Max & Mean SVL & S.E & $\mathbf{n}$ & Min-Max & Mean SVL & S.E \\
\hline \multirow{11}{*}{ 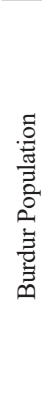 } & 0 & 22 & $24.9-39.0$ & 32.7 & 0.72 & & & & & & & & & & & & \\
\hline & 1 & & & & & 11 & $35.8-49.8$ & 43.9 & 1.36 & & & & & & & & \\
\hline & 2 & & & & & 2 & $55.0-65.0$ & 60.0 & 5.00 & 4 & $53.0-63.0$ & 57.0 & 2.12 & 6 & $53.0-68.0$ & 58.5 & 2.35 \\
\hline & 3 & & & & & & & & & 4 & $72.0-87.0$ & 80.7 & 3.54 & 5 & $73.0-78.0$ & 76.0 & 1.05 \\
\hline & 4 & & & & & & & & & 6 & $76.0-89.0$ & 83.1 & 1.99 & 7 & $75.0-89.0$ & 81.5 & 2.02 \\
\hline & 5 & & & & & & & & & 4 & $73.3-92.0$ & 83.6 & 3.91 & 5 & $70.0-96.0$ & 81.0 & 5.18 \\
\hline & 6 & & & & & & & & & 5 & $84.0-102.0$ & 93.4 & 3.44 & 5 & $76.0-99.0$ & 88.4 & 4.20 \\
\hline & 7 & & & & & & & & & 4 & $98.0-105.0$ & 101.7 & 1.65 & 4 & $86.0-97.0$ & 92.5 & 2.40 \\
\hline & 8 & & & & & & & & & 5 & $102.0-110.0$ & 106.0 & 1.52 & 2 & $96.0-102.0$ & 99.0 & 3.00 \\
\hline & 9 & & & & & & & & & 2 & $112.0-115.4$ & 113.7 & 1.70 & 1 & 105.0 & 105.0 & \\
\hline & 10 & & & & & & & & & 1 & 113.0 & 113.0 & & & & & \\
\hline \multirow{10}{*}{ 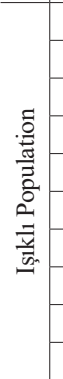 } & 0 & 7 & $27.0-37.0$ & 31.8 & 1.37 & & & & & & & & & & & & \\
\hline & 1 & & & & & 5 & $37.0-48.0$ & 42.0 & 1.92 & & & & & & & & \\
\hline & 2 & & & & & 2 & $51.8-52.2$ & 51.9 & 0.21 & 2 & $65.0-68.0$ & 66.5 & 1.50 & 4 & $57.9-65.0$ & 62.0 & 1.59 \\
\hline & 3 & & & & & & & & & 9 & $58.6-77.0$ & 67.2 & 2.56 & 7 & $58.0-69.0$ & 64.4 & 1.64 \\
\hline & 4 & & & & & & & & & 7 & $62.0-82.0$ & 73.2 & 2.78 & 7 & $65.0-79.0$ & 70.5 & 1.96 \\
\hline & 5 & & & & & & & & & 4 & $77.0-88.0$ & 82.8 & 2.29 & 6 & $69.3-84.0$ & 75.7 & 1.96 \\
\hline & 6 & & & & & & & & & 4 & $73.3-87.0$ & 80.1 & 2.83 & 5 & $71.1-88.0$ & 77.9 & 2.81 \\
\hline & 7 & & & & & & & & & 7 & $80.8-95.0$ & 89.0 & 1.79 & 3 & $82.0-86.0$ & 84.2 & 1.18 \\
\hline & 8 & & & & & & & & & 2 & $92.9-104.2$ & 98.5 & 5.69 & 2 & $86.7-92.0$ & 89.3 & 2.67 \\
\hline & 9 & & & & & & & & & 2 & $96.4-110.7$ & 103.5 & 7.16 & & & & \\
\hline
\end{tabular}

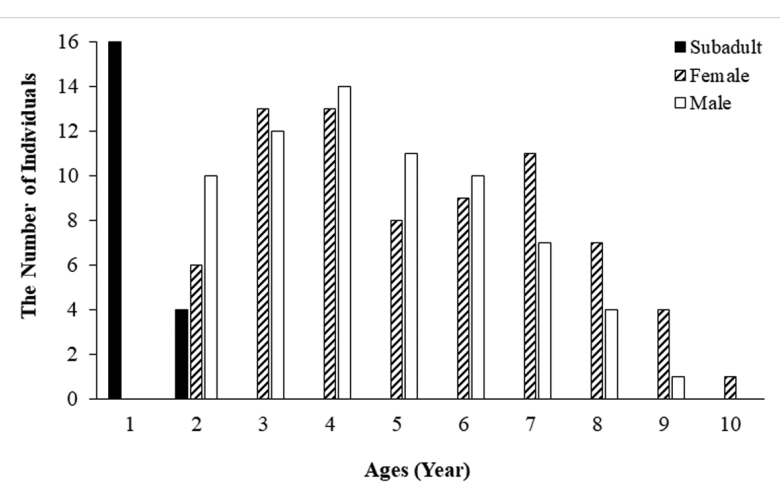

Figure 2. Age distributions of P. caralitanus from the two populations.v.

(Burdur; $\mathrm{t}=1.520 ; \mathrm{df}=68 ; \mathrm{p}>0.05$, Işıklı Lake; $\mathrm{t}=$ $1.120 ; \mathrm{df}=69 ; \mathrm{p}>0.05)$. Furthermore, the sex-specific age structure did not differ significantly between populations $(\mathrm{t}=0.800 ; \mathrm{df}=70 ; \mathrm{p}>0.05$ for females and $\mathrm{t}=$ $0.886 ; \mathrm{df}=67 ; \mathrm{p}>0.05$ for males). The age distribution is shown in Figure 2. Our results showed that maturity ages were two or three years in both sexes. Longevity of males was eight years in the Işıklı population and nine years in the Burdur population, whereas in females, it was nine years in Işıklı and 10 years in Burdur. The mean ESP of females and males was estimated as 6.61 and 6.15 years, respectively. Similarly, the mean survival rates of females and males were calculated as 0.84 and 0.83 , respectively. Growth patterns of the two populations were compared according to the von Bertalanffy growth model (Figure 3). We found that the growth coefficients were higher in females than in males, while the peak growth
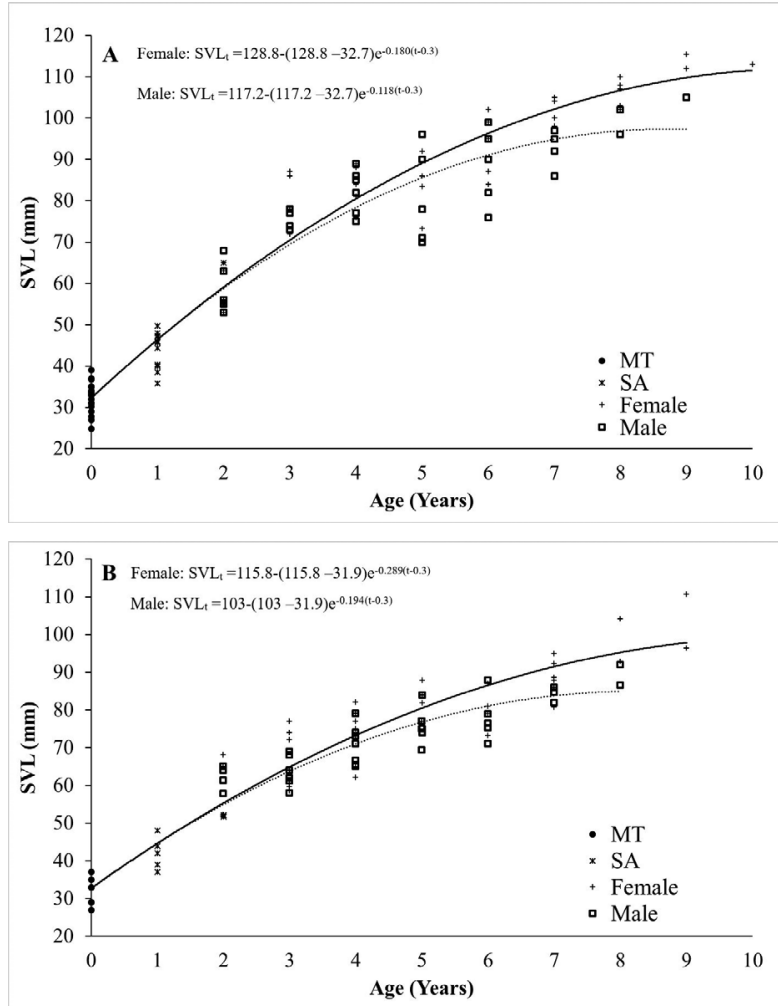

Figure 3. Relationship between SVL and age in Burdur population (A) and Işıklı population (B) of $P$. caralitanus, as expressed by Von Bertalanffy growth curves. MT: Newly Metamorphosed, SA: Subadults.

rate was found to be in the age range of 1-2 years. This slowly decreased after that to the age range of 3-4 years in both sexes (Figure 4). 
Table 2. Comparison of age, size and growth parameters of $P$. caralitanus in two populations and cognate species: a comparison with existing literature. (AM: Age at Maturity, k: Growth coefficient, ESP: Adult life expectancy, SR: Survival rate).

\begin{tabular}{|c|c|c|c|c|c|c|c|c|c|c|c|c|}
\hline Species & Locality & Sex & $\mathbf{N}$ & $\begin{array}{c}\text { Mean SVL } \\
(\mathbf{m m})\end{array}$ & $\begin{array}{c}\text { Asymptotic } \\
\text { size (mm) }\end{array}$ & $\begin{array}{c}\text { Max age } \\
\text { (years) }\end{array}$ & \begin{tabular}{|c|}
$\mathrm{AM}$ \\
(years)
\end{tabular} & $\begin{array}{c}\text { Mean age } \\
\text { (years) }\end{array}$ & $\mathbf{k}$ & ESP & SR & References \\
\hline \multirow{14}{*}{ 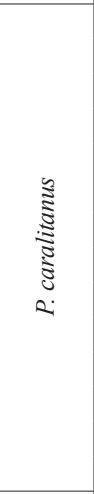 } & \multirow[t]{2}{*}{ Işıklı Lake, Turkey } & $\mathrm{M}$ & 34 & 72.62 & 103.00 & 8 & 2 & 4.53 & 0.194 & 5.68 & 0.81 & \multirow[t]{4}{*}{ Present study } \\
\hline & & $\mathrm{F}$ & 38 & 79.16 & 115.80 & 9 & $2-3$ & 5.03 & 0.289 & 6.03 & 0.82 & \\
\hline & \multirow[t]{6}{*}{ Beyşehir Lake, Turkey } & M & 35 & 80.63 & 117.20 & 9 & 3 & 4.66 & 0.118 & 6.62 & 0.84 & \\
\hline & & $\mathrm{F}$ & 35 & 89.40 & 128.80 & 10 & $2-3$ & 5.43 & 0.180 & 7.19 & 0.85 & \\
\hline & & M & 38 & 75.56 & 109.00 & 9 & $3-4$ & 5.01 & 0.180 & & & \multirow{2}{*}{$\begin{array}{l}\text { Erişmiş and Chinsamy } \\
2010\end{array}$} \\
\hline & & $\mathrm{F}$ & 51 & 92.05 & 126.24 & 10 & $3-4$ & 6.01 & 0.160 & & & \\
\hline & & $\mathrm{M}$ & 96 & 90.41 & 111.35 & 9 & 3 & 5.63 & & 7.52 & 0.81 & \multirow[t]{8}{*}{ Erişmiş 2018} \\
\hline & & $\mathrm{F}$ & 73 & 98.29 & 126.50 & 10 & 3 & 6.33 & & 7.94 & 0.82 & \\
\hline & \multirow[t]{2}{*}{ Karamık Lake, Turkey } & $\mathrm{M}$ & 66 & 82.33 & 99.48 & 7 & 3 & 4.86 & & 6.26 & 0.76 & \\
\hline & & $\mathrm{F}$ & 76 & 88.36 & 111.63 & 8 & 3 & 5.30 & & 6.83 & 0.78 & \\
\hline & \multirow[t]{2}{*}{ Işıklı Lake, Turkey } & $\mathrm{M}$ & 49 & 73.06 & 93.68 & 6 & 2 & 3.69 & & 5.50 & 0.73 & \\
\hline & & $\mathrm{F}$ & 47 & 82.54 & 106.72 & 8 & 2 & 4.80 & & 7.01 & 0.78 & \\
\hline & \multirow[t]{2}{*}{ Eğirdir Lake, Turkey } & $\mathrm{M}$ & 90 & 86.44 & 110.12 & 8 & 3 & 5.42 & & 7.32 & 0.79 & \\
\hline & & $\mathrm{F}$ & 97 & 94.52 & 120.28 & 10 & 3 & 6.21 & & 8.20 & 0.81 & \\
\hline \multirow{14}{*}{ 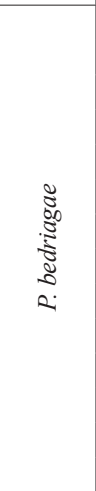 } & \multirow{2}{*}{$\begin{array}{c}\text { Vali Recep Yazıcıoğlu Dam, Denizli, } \\
\text { Turkey }\end{array}$} & $\mathrm{M}$ & 30 & 63.01 & 80.17 & 9 & 2 & 4.59 & 0.183 & & & \multirow[t]{10}{*}{ Başkale et al. 2018} \\
\hline & & $\mathrm{F}$ & 22 & 71.20 & 83.75 & 9 & 2 & 5.20 & 0.270 & & & \\
\hline & \multirow[t]{2}{*}{ Süleymanlı Lake, Denizli, Turkey } & M & 24 & 68.01 & 73.80 & 11 & 2 & 6.44 & 0.371 & & & \\
\hline & & $\mathrm{F}$ & 25 & 76.63 & 82.67 & 12 & 2 & 6.46 & 0.219 & & & \\
\hline & \multirow[t]{2}{*}{ Acıgöl Lake, Denizli, Turkey } & $\mathrm{M}$ & 15 & 63.09 & 70.04 & 9 & 2 & 5.59 & 0.370 & & & \\
\hline & & $\mathrm{F}$ & 17 & 71.93 & 80.79 & 9 & 2 & 5.13 & 0.237 & & & \\
\hline & \multirow[t]{2}{*}{ Ornaz Valley, Denizli, Turkey } & M & 14 & 69.49 & 78.64 & 12 & 2 & 5.9 & 0.193 & & & \\
\hline & & $\mathrm{F}$ & 14 & 81.14 & 96.41 & 12 & 2 & 6.8 & 0.331 & & & \\
\hline & \multirow[t]{2}{*}{ Pooled localities } & M & 80 & 65.78 & 88.10 & 12 & 2 & 5.65 & 0.239 & & & \\
\hline & & $\mathrm{F}$ & 81 & 74.31 & 91.50 & 12 & 2 & 5.79 & 0.346 & & & \\
\hline & \multirow[t]{4}{*}{ Sülüklü Lake Manisa, Turkey } & $\mathrm{M}$ & 14 & 56.10 & 73.20 & 4 & 2 & 2.5 & \multirow[t]{2}{*}{0.300} & & & \multirow[t]{2}{*}{ Çiçek et al. 2011} \\
\hline & & $\mathrm{F}$ & 22 & 64.50 & 92.40 & 5 & 2 & 2.95 & & & & \\
\hline & & M & 51 & 59.80 & 120.00 & 7 & 2 & 3.45 & 0.220 & & & İsmail and Çiçek 2017 \\
\hline & & $\mathrm{F}$ & 76 & 59.78 & 137.00 & 9 & 2 & 4.33 & 0.360 & & & \\
\hline & Yıldızlı Stream, Trabzon, Turkey & $\mathrm{M}$ & 38 & 64.58 & & 7 & $3-4$ & 3.90 & & & & Y1lmaz et al. 2005 \\
\hline & & $\mathrm{F}$ & 11 & 76.64 & & 6 & $3-4$ & 3.72 & & & & \\
\hline & Lake Vistonis, Lagos, Greece & $\mathrm{M}$ & 52 & 69.03 & 93.40 & 5 & 1 & 2.96 & 0.570 & & & Kyriakopoulou- \\
\hline & & $\mathrm{F}$ & 56 & 82.38 & 107.50 & 5 & 1 & 3.73 & 0.540 & & & Sklavounou et al. 2008 \\
\hline & Milicz Ponds Reserve, Stawno, Poland & $\mathrm{M}$ & 32 & 72.20 & 90.00 & 6 & 2 & 3.7 & 0.760 & & & Socha and Ogielska \\
\hline & & $\mathrm{F}$ & 38 & 79.80 & 102.30 & 7 & 3 & 4.4 & 0.590 & & & 2010 \\
\hline & Artvin (Borçka, Lake Karagöl), Turkey & $\mathrm{M}$ & 20 & 72.96 & & 8 & 2 & 5.15 & & & & Gül et al. 2011 \\
\hline & & F & 25 & 63.49 & & 7 & 2 & 4.20 & & & & \\
\hline$\stackrel{5}{2}$ & Dörtyol, Hatay, Turkey & $\mathrm{M}$ & 20 & 64.70 & & 11 & 4 & 5.50 & & & & \\
\hline$\widetilde{3}$ & & $\mathrm{~F}$ & 19 & 76.74 & & 7 & 3 & 5.58 & & & & \\
\hline 2 & Verkhne-Tagil Reservoir, Tagil and & $\mathrm{M}$ & - & - & - & - & - & - & - & - & - & Ivanova and Zhigalski. \\
\hline & Vogulka rivers, Middle Urals & $\mathrm{F}$ & & 92.80 & 116.00 & 9 & 2 & 5.4 & & & & \\
\hline & The Reftinskii Reservoir Reft River, & $\mathrm{M}$ & - & - & - & - & - & - & - & - & - & \\
\hline & Middle Urals & $\mathrm{F}$ & 26 & 112.90 & 132.00 & 8 & 2 & 4.4 & & & & \\
\hline & The north of Lorestan Province, central & $\mathrm{M}$ & 26 & 71.14 & & 11 & 3 & 6.43 & & & & Ashkavandi et al. 2012 \\
\hline & Zagros, Iran & $\mathrm{F}$ & 14 & 74.05 & & 7 & 3 & 4.5 & & & & \\
\hline & North-western part of Croatia & $\mathrm{M}$ & 5 & & & 13 & 3 & 8 & & & & Cavlovic et al. 2018 \\
\hline & & $\mathrm{F}$ & & & & & & & & & & \\
\hline
\end{tabular}

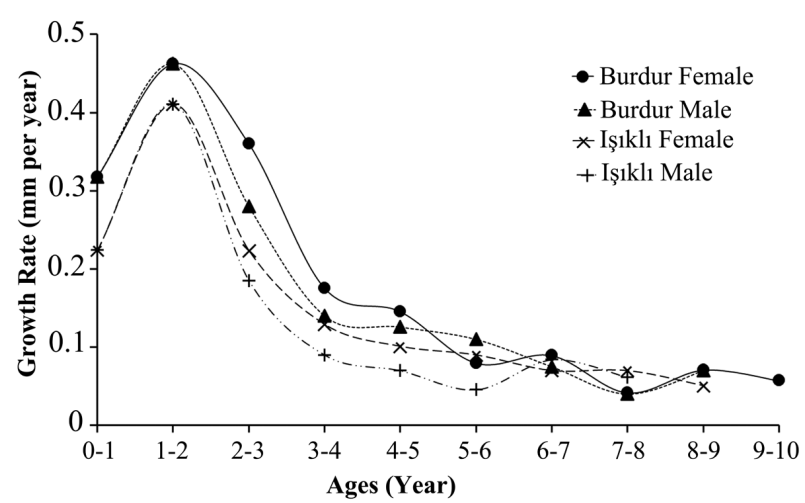

Figure 4. Annual growth rate changes of males and females of P. caralitanus between populations

\section{Discussion}

In this study, we investigated the demographic structure of $P$. caralitanus, using the skeletochronology method which provides information about the individual variation of life history traits and data on growth and age at maturity. According to the results, the age structure of $P$. caralitanus was quite similar in our two different study sites. The results showed similarity with the previous studies (Table 2). In contrast to Erişmiş (2018), we estimated the age of sexual maturity as 2 and 3 years for males and females, respectively. Although Erişmiş (2018) accepted individuals as subadults with an SVL less than 
$65 \mathrm{~mm}$, we found mature individuals less than $65 \mathrm{~mm}$ of SVL in both populations (Table 1). Similar age distributions were observed in other cognate species of Pelophylax sp. ( $P$. ridibundus and $P$. bedriagae) that occur in Turkey (Table 2). We found the mean and maximum ages of females were higher than those of males which means female individuals live longer than male individuals and this information is consistent with literature (Tsiora and Kyriakopoulou-Sklavounou 2002; Socha and Ogielska 2010; Çiçek et al. 2011; Gül et al. 2011; Erişmiş 2018).

Our results showed that growth rates of $P$. caralitanus were high until sexual maturity and decreased thereafter. The growth coefficients $(\mathrm{k})$ were higher in females than in males as in many amphibian species (Guarino et al. 2003; Patrelle et al. 2012). For both sexes, the growth curve was quite similar to other populations of $P$. caralitanus (Erişmiş and Chinsamy 2010; Erişmiş 2018) and other amphibian species, such as Rana temporaria (Ryser 1988), Rana subaquavocalis (Platz et al. 1997) and P. bedriagae (Çiçek et al. 2011; Başkale et al. 2018). In addition, the growth rate is lower than the values reported for European populations of $P$. ridibundus (Kyriakopoulou-Sklavounou et al. 2008; Socha and Ogielska 2010).

Females were larger than males in both populations like other Anuran species (Shine 1979). We found that individuals of the Burdur population were larger than the Işı1klı population in both genders. Similarly, Erişmiş (2018) claimed that the mean body sizes of individuals from the Işıklı population were smaller than the other populations (see Table 2). However, Başkale et al. (2017) also showed body size variations in five populations of $P$. caralitanus (Ağlasun, Suğla, Gölcük, Akburun, Yazıköy populations), these variations being not statistically significant.

In conclusion, we provided data on body size, growth rate, adult life expectancy, survival rate, age at maturity and longevity of $P$. caralitanus from the Burdur and Işıklı Lake populations, using the skeletochronology method. Burdur and Işıklı Lake populations showed differences in body size, ESP and survival rates. These data provide valuable information on life-history traits of this species in order to develop more efficient conservation measures.

\section{Acknowledgements}

This study was a part of the first author's M.Sc. thesis. The permissions for field work, handling and laboratory studies of the frogs were issued by the Animal Ethics Committee of Pamukkale University, Ministry of Forestry and Water Affairs, General Directorate of Nature Conservation and Natural Parks and Turkish Ministry of Food, Agriculture and Livestock. We would like to thank to Pamukkale University Scientific Research Projects Unit - BAP (2016FEBE047) for their support during this study. We would also like to thank Ayşe Sevay Ulubeli for her assistance in the laboratory studies.

\section{References}

Alpagut N, Falakalı B (1995) Karyotype analysis of two Rana ridibunda (Ranidae; Anura) populations in Turkey. Israel Journal of Zoology 41: 523-531.

Altunışık A, Özdemir N (2013) Body size and age structure of a highland population of Hyla orientalis Bedriaga, in northern Turkey. Herpetozoa 26: 49-55.

Arıkan H (1988) On a new form of Rana ridibunda from Turkey. Istanbul Universitesi Fen Fakultesi Mecmuası 53: 81-87.

Arıkan H, Özeti N, Çevik IE, Tosunoğlu M (1994) Distribution of Rana ridibunda caralitana (Anura: Ranidae) in Lake District. Turkish Journal of Zoology 18: 141-145.

Ashkavandi S, Gharzi A, Abbassi M (2012) Age determination by skeletochronology in Rana ridibunda (Anuran: Amphibia). Asian Journal of Experimental Biological Sciences 3: 156-162.

Atatür KM, Arıkan H, Mermer A (1989-1990) A taxonomical investigation on Rana ridibunda Pallas (Anura, Ranidae) populations from the Lakes District-Anatolia. Istanbul Universitesi Fen Fakultesi Mecmuası 54: 79-83.

Başkale E, Çapar D (2016) Detection probability and habitat selection of the Beyşehir Frog, Pelophylax caralitanus (ARIKAN 1988), in southwestern Anatolia, Turkey. Russian Journal of Herpetology 23: 205-214.

Başkale E, Sözbilen D, Polat F (2017) Population ecology and distribution of Pelophylax caralitanus (Arrkan, 1988), in the Lakes District, southwestern Anatolia, Turkey. Herpetozoa 29: 143-153

Başkale E, Ulubeli SA, Kaska Y (2018) Age structures and growth parameters of the Levantine frog, Pelophylax bedriagae, at different localities in Denizli, Turkey. Acta Herpetologica 13: 147-154

Beerli P, Hotz H, Tunner HG, Heppich S, Uzzell T (1994) Two new water frog species from the Aegean Islands Crete and Karpathos (Amphibia, Salientia, Ranidae). Notulae Naturae 470:1-9.

Bertalanffy L von (1938) A quantitative theory of organic growth. Human Biology 10: 181-213.

Bodenheimer FS (1944) Introduction to the knowledge of the Amphibia and Reptilia of Turkey. Istanbul Universitesi Fen Fakultesi Mecmuas1 9: 1-83.

Budak A, Tok CV, Ayaz D (2000) On specimens of Rana ridibunda Pallas, 1771 (Anura: Ranidae) collected from Işıklı Lake (Çivril-Denizli). Turkish Journal of Zoology 24: 135-137.

Castanet J, Francillon-Vieillot H, Meunier FJ, De Ricqlès A (1993) Bone and individual aging, In: Hall BK (Eds) Bone, Vol. 7: Bone growth - B. CRC Press, Boca Raton, Florida, 245-283.

Castanet J, Smirina EM (1990) Introduction to the skeletochronological method in amphibians and reptiles. Annales des Sciences Naturelles 11: $191-196$

Čavlović K, Buj I, Karaica D, Jelić D, Choleva L (2018) Composition and age structure of the Pelophylax esculentus complex (Anura; Ranidae) population in inland Croatia. Salamandra 54: 11-20.

Çiçek K, Kumaş M, Ayaz D, Mermer A, Engin ŞD (2011) Age structure of Levant water frog, Pelophylax bedriagae, in Lake Sülüklü (Western Anatolia, Turkey). Basic and Applied Ecology 25: 73-80. https://doi.org/10.11160/bah.11012

Düşen S, Öz M, Tunç MR, Kumlutaş Y, Durmuş H (2004) Three New Localities for Rana bedriagae caralitana Arıkan, 1988 (Anura: Ranidae) in the West Mediterranean Region. Turkish Journal of Zoology 28: 115-117. 
Erişmiş UC (2018) Age, size, and growth of the Turkish endemic frog Pelophylax caralitanus (Anura: Ranidae). The Anatomical Record 301:1224-1234. https://doi.org/10.1002/ar.23758

Erişmiş UC, Chinsamy A (2010) Ontogenetic changes in the epiphyseal cartilage of Rana (Pelophylax) caralitana (Anura: Ranidae). The Anatomical Record 293: 1825-1837. https://doi.org/10.1002/ ar. 21241

Esteban M, Sanchiz B (2000) Differential growth and longevity in low and high altitude Rana iberica (Anura, Ranidae). Herpetological Journal 10: 19-26.

Guarino FM, Cammarota M, Angelini F (1999) Skeletochronology on femurs and phalanges from some species of Italian amphibians. Rivista di Biologia 38: 1-10.

Guarino FM, Erişmiş UC (2008) Age determination and growth by skeletochronology of Rana holtzi, an endemic frog from Turkey. Italian Journal of Zoology 75: 237-242. https://doi. org/10.1080/11250000701883427

Guarino FM, Lunardi S, Carlomagno M, Mazzotti S (2003) A skeletochronological study of growth, longevity, and age at sexual maturity in a population of Rana latastei (Amphibia, Anura). Journal of Bioscience 28: 775-782. https://doi.org/10.1007/BF02708438

Gül S, Özdemir N, Üzüm N, Olgun K, Kutrup B (2011) Body size and age structure of Pelophylax ridibundus populations from two different altitudes in Turkey. Amphibia-Reptilia 32: 287-292. https://doi. org/10.1163/017353711X559094

İsmail İB, Çiçek K (2017) Population size, age structure and life cycle of Levant water frog, Pelophylax bedriagae (Camerano, 1882) (Amphibia: Anura: Ranidae) in Lake Sülüklü (Manisa). Ege Journal of Fisheries and Aquatic Sciences 34: 169-177. https://doi. org/10.12714/egejfas.2017.34.2.08

Ivanova NL, Zhigalski OA (2011) Demographic features of populations of the marsh frog (Rana ridibunda Pall.) introduced into water bodies of the Middle Urals. Russian Journal of Ecology 42: 400-406. https://doi.org/10.1134/S1067413611050067

Jdeidi T (2000) Enzyme polymorphism, morphometric and bioacoustic studies in water frog complex in Turkei. Ph.D Thesis. Middle East Technical University, Ankara, Turkey.

Kaya U, Çevik IE, Erişmiş UC (2002) New Distributional Records for Rana bedriagae caralitana in Anatolia. Turkish Journal of Zoology 26: $381-383$.

Kyriakopoulou-Sklavounou P, Stylianou P, Tsiora A (2008) A skeletochronological study of age, growth and longevity in a population of the frog Rana ridibunda from southern Europe. Zoology 111: 30-36. https://doi.org/10.1016/j.zool.2007.03.002

Lovich JE, Gibbons JW (1992) A review of techniques for quantifying sexual size dimorphism. Growth Development and Aging 56: 269-281.

Miaud C, Andreone F, Ribéron A, De Michelis S, Clima V, Castanet J, Francillon-Vieillot H, Guyétant R (2001) Variations in age, size at maturity and gestation duration among two neighbouring populations of the alpine salamander (Salamandra lanzai). Journal of Zoology 254: 251-260. https://doi.org/10.1017/S0952836901000760

Olgun K, Üzüm N, Avcı A, Miaud C (2005) Age, size and growth of the Southern Crested Newt Triturus karelinii (Strauch, 1870) in a population from Bozdağ (Western Turkey). Amphibia-Reptilia 26: 223-230. https://doi.org/10.1163/1568538054253465
Öz M, Kaska Y, Kumlutaş, Y, Kaya U, Avcı A, Üzüm N, Yeniyurt C, Akarsu F, Kasparek M (2009) Pelophylax caralitanus. The IUCN Red List of Threatened Species 2009: e.T135806A4203649. https:// doi.org/10.2305/IUCN.UK.2009.RLTS.T135806A4203649.en [ Downloaded on 03 April 2019]

Patrelle C, Hjernquist MB, Laurila A, Söderman F, Merila J (2012) Sex differences in age structure, growth rate and body size of common frogs Rana temporaria in the subarctic. Polar Biology 35: 15051513. https://doi.org/10.1007/s00300-012-1190-7

Platz JE, Lathrop A, Hofbauer L, Vradenburg M (1997) Age distribution and longevity in the Ramsey canyon leopard frog, Rana subaquavocalis. Journal of Herpetology 31: 552-557. https://doi. org $10.2307 / 1565608$

Plötner J, Ohst T, Böhme W, Schreiber R (2001) Divergence in mitochondrial DNA of Near Eastern water frogs with special reference to the systematic status of Cypriote and Anatolian populations (Anura, Ranidae). Amphibia-Reptilia 22: 397-412. https://doi. org/10.1163/15685380152770363

Robson DS, Chapman DG (1961) Catch curves and mortality rates. Transactions of the American Fisheries Society 90:181-189. https:// doi.org/10.1577/1548-8659(1961)90[181:CCAMR]2.0.CO;2

Ryser J (1988) Determination of growth and maturation in the common frog, Rana temporaria, by skeletochronology. Journal of Zoology 216: 673-685. https://doi.org/10.1111/j.1469-7998.1988.tb02465.x

Seber GAF (1973) The Estimation of Animal Abundance. Hafner Press. New York, NY, USA.

Shine R (1979) Sexual selection and sexual dimorphism in Amphibia. Copeia 1979: 297-306. https://doi.org/10.2307/1443418

Sinsch U (2015) Review: Skeletochronological assessment of demographic life-history traits in amphibians. Herpetological Journal 25: $5-13$.

Smirina EM (1994) Age determination and longevity in amphibians. Gerontology 40: 133-146. https://doi.org/10.1159/000213583

Socha M, Ogielska M (2010) Age structure, size and growth rate of water frogs from central European natural Pelophylax ridibundus-Pelophylax esculentus mixed populations estimated by skeletochronology. Amphibia-Reptilia 31: 239-250. https://doi. org/10.1163/156853810791069119

SPSS (2011) IBM SPSS Statistics for Windows, Version 20.0. IBM Corp. Released 2011. Armonk, NY: IBM Corp.

Tsiora A, Kyriakopoulou-Sklavounou P (2002) A skeletochronological study of age and growth in relation to adult size in the water frog Rana epeirotica. Zoology 105: 55-60. https://doi.org/10.1078/09442006-00049

Üzüm N, Avcı A, Özdemir N, Ilgaz Ç, Olgun K (2011) Body size and age structure of a breeding population portion of the Urmia salamander, Neurergus crocatus Cope, 1862 (Caudata: Salamandridae). Italian Journal of Zoology 78: 209-214. https://doi. org/10.1080/11250001003636679

Üzüm N, Olgun K (2009) Age and growth of the southern crested newt, Triturus karelinii (Strauch 1870), in a lowland population from northwest Turkey. Acta Zoologica Academiae Scientiarum Hungaricae 55: 55-65. https://doi.org/10.1655/08-008.1

Yılmaz N, Kutrup, B, Çobanoğlu U, Özoran Y (2005): Age determination and some parameters of a Rana ridibunda population in Turkey. Acta Zoologica Academiae Scientiarum Hungaricae 51: 67-74. 